\title{
Creating Community Based Environmental Awareness with Social Media: A Kenyan perspective
}

Paul Waititu, County Government of Nakuru, Kenya

\begin{abstract}
One of the roles of community education is keeping citizens more informed on the need to conserve their environment. However, for this to be effective in the digital era, the use of modern communication tools is required to keep pace with current technological developments. One of these tools is social media, which is enormously popular and is used by both individuals and organisations for online communication. This paper analyses the role of social media in community-based organisations (CBOs) in creating environmental awareness through community education in Kenya. A non-probability sample comprising nine CBOs in Nakuru City was used to explore activities focused on environmental issues. Data were collected and analysed from a total of 98 respondents who participated in an online survey. It was concluded that the use of social media for environmental awareness in CBOs was minimal, but there is potential in its use as a social learning environment for creating environmental awareness. The study recommends capacity building and open online communication as a means of promoting the use of social media in creating environmental awareness through community education programmes.
\end{abstract}

Keywords: environmental management, environmental awareness, community based organisation ( $C B O)$, community education, social media

\section{Introduction}

Recent theoretical developments have suggested that complex issues can often easily be resolved at the local level through community initiatives (Hidayat \& Stoecker, 2018). This brings to the fore the critical role played by community based organisations (CBOs) in addressing problems facing their communities. CBOs have been at the forefront in driving agendas for addressing various issues that are unique to specific communities at the grassroots level, thus the focus on $\mathrm{CBO}$ s in this survey. $\mathrm{CBO}$ s are entities that are constituted by local community members to address issues that affect them at the local level. Various CBOs focus their activities in the field of environment. These organisations endeavour to promote environmental conservation through community education and to protest against any act or omission that may facilitate environmental degradation.

More and more countries are striving to upgrade their industrial capacities to meet the market demand, resulting in high levels of environmental pollution. Ironically, 
industrialisation and its proceeds have mainly been used as the yardstick for measuring the level of a country's economic development (Nazeer, Tabassum \& Alam, 2016). Proponents of environmental management have used $\mathrm{CBO}$ s as vehicles for environmental activism, community education and political engagement. Through environmental activism and community education, citizens are able to take to task the authorities concerned and demand accountability from various environmental polluters. CBOs are often used as forums to regulate pollutants emanating from industries, though attempts to thwart their efforts are frequent.

Environmental activism is described by Zhang and Skoric (2018, p. 832) as "social movement-type activities, such as getting involved in fundraising campaigns, signing petitions, and writing letters to policy makers". Environmental management is often controversial (Hidayat \& Stoecker, 2018). In the context of this study, community education can be considered as activities that empower community members to deal with various emerging environmental concerns by providing the necessary knowledge, skills and attitudes, while at the same time utilising the available community resources, such as local manpower and technologies (Saepudin \& Mulyono, 2019; Calitz, Cullen \& Odendaal, 2020).

There is a growing body of literature that recognises the importance of social media in promoting community education and creating environmental awareness (Rahim \& Jalaladeen, 2016; Roshandel, Labafi \& Robati, 2016; Hidayat \& Stoecker, 2018; Zhang \& Skoric, 2018; Lopez, Magliocca \& Crooks, 2019; Saepudin \& Mulyono, 2019; Severo et al., 2019; Bramwell-Lalor et al., 2020). However, despite the wide use of social media, research on its role in communicating concerns threatening environmental sustainability in the context of the local communities in Kenya is minimal. Moreover, the role of social media as an ideal social learning environment for creating awareness and communicating ideas on environmental management by CBOs is not well covered (Du et al., 2018; Hidayat \& Stoecker, 2018). To address this gap in the literature, this study attempted to explore the use of social media to enhance environmental management awareness in the context of CBOs in Kenya.

The paper is structured as follows: the theoretical background, research methodology and study findings are presented, followed by a discussion and conclusions.

\section{Literature review}

\section{Social networking theory}

This research draws insights from social network theory, which emphasises social interactions (Granovetter, 1973; Granovetter, 1983; Tsai, 2012). As argued in various studies (Kane et al., 2014; Chung \& Crawford, 2016), social networks can help to gauge online social relationships, through social media platforms and their influence on creating a suitable social learning environment for environmental awareness. Online social networks facilitate users to interact and create relationships through various online networking tools, in addition to sharing information (Kane et al., 2014). Therefore, online social 
networks can be considered a learning environment in addressing various factors, such as perceptions, behaviours and attitudes, which are important for enhancing environmental awareness potential.

\section{Environmental pollution from industrialised nations}

Unknown to most citizens in undeveloped countries, $78 \%$ of global environmental pollutants emanates from only a handful of powerful industrialised nations (United Nations Environmental Programme, 2019). Unfortunately, the same nations are mandated to set the agendas and policies on environmental protection and sustainability. Despite the United Nations Environmental Programme (UNEP) headquarters being based in Kenya, most of its financial obligations and key decisions are made by developed nations, who are also the main environmental polluters. Moreover, most international and regional environmental watchdogs receive their funding from the same nations (Zhang \& Skoric, 2018). This is why most international treaties and policies on environmental sustainability are either skewed or overlooked in favour of environmentally polluting investments and innovations. Moreover, some of the industrialised nations are unwilling to ratify or fully support efforts to promote environmental sustainability if it involves drastic reduction of industrial emissions or safe waste disposal.

With the enactment of stringent legislation on environmental protection in some parts of America and Europe, following aggressive environmental activism, some of these countries have devised ways of shipping out and dumping their hazardous waste in developing countries in Asia and Africa, who welcome these deadly imports due to poverty, lack of political will and weak environmental regulations (Nazeer et al., 2016). The waste is classified either as donations of used goods, refurbished equipment or materials for dubious offshore recycling trade (Ferronato \& Torretta, 2019; Sembiring, 2019).

\section{Environmental pollution from developing nations}

Apart from the pollution attributed to the developed world, developing countries are not entirely blameless. The level of air, water and ground pollution in those countries is growing exponentially, with little or no control (Nazeer et al., 2016; Mannucci \& Franchini, 2017). The legislation and environmental watchdogs in these countries have insufficient capacity to deal with this pollution. It is rare to find a body of clean water in Africa, as so many have been turned into disposal sites for huge volumes of solid and liquid waste. A recent study by Nazeer et al. (2016) revealed that many water bodies can no longer support any aquatic life due to high toxic levels from domestic, industrial, agricultural and other waste. Moreover, ground and rain water are no longer safe sources for drinking water due to the high level of pollution. Such information can be shared though robust and participatory community education programmes based at the local level. 


\section{The role of CBOs in environmental awareness}

Recent studies (Rahim \& Jalaladeen, 2016; UNEP, 2019) reveal that the world community is now more concerned about the nature and extent of the present state of environmental degradation and its impact on future generations. To address this concern, several community-based pressure groups and organisations have developed community education programmes to advocate awareness on the need to live in a clean, healthy and sustainable environment, by highlighting pollution effects such as global warming and other hazards (Hidayat \& Stoecker, 2018; Kaur \& Chahal, 2018; Saepudin \& Mulyono, 2019; Severo et al., 2019). Some of these entities advocate for environmental consumerism programmes which target community behaviour. According to Zhang and Skoric (2018), environmental consumerism refers to those common and daily behaviours adopted by individuals who have become more conscious of their environment. Advocates of environmental consumerism, for example Zhang and Skoric (2018), have argued that this can increase and extend the level of environmental awareness. Environmental awareness has been defined by $\mathrm{Du}$ et al. (2018, p. 3) as "the ability of an individual to understand the connection existing between: (a) human activities, (b) the current status of environmental quality, and (c) his/ her willingness to take part in environment activities". However, a study by Severo et al. (2019) showed that despite efforts to promote awareness, community involvement in solving various environmental issues is not always evident. Environmental awareness and involvement allows individuals and communities to gain insight into the fragility of the environment and the need to maintain sound ecosystems, protect them from degradation and adopt sustainability policies and practices.

According to some scholars (Du et al., 2018; Kaur \& Chahal, 2018; Lopez et al., 2019), people who do not understand their environmental issues may not see the importance of addressing environmental concerns, hence the need to strengthen community education on environmental awareness at all levels in the community. Importantly, citizens who are conscious of their environment are likely to modify their behaviours in support of sustainability efforts for future generations. Moreover, community members may develop positive attitudes towards environmental sustainability that may evoke emotional responses towards environmental concerns. Subsequently, this may trigger favourable perceptions and actions suitable for improving environmental management. Thus, CBOs dealing with environmental issues have a critical role to play in educating citizens (particularly those at the local level) regarding environmental sustainability through community based mobilisation and training. Additionally, equipping local communities with enough knowledge and awareness can motivate positive behavioural change and create 'conservation ambassadors' (Saepudin \& Mulyono, 2019).

\section{The use of social media in environmental awareness}

A recent study by Kaur and Chahal (2018) indicated that creating environmental awareness through the sharing of knowledge requires various offline or online tools of communication. The internet is becoming increasingly popular, offering a diversity of communication 
opportunities cutting across various topics and issues. Notably, Kaur and Chahal (2018) specified that prevailing lifestyles, technological advancement and educational changes can be credited to unprecedented growth in the use of the internet and its allied social networking tools and platforms. Of interest to this study is the social media phenomenon, which incorporates various synchronous and asynchronous online tools. Social media is described by Omar, Dahalana and Yusoff (2016), Rahim and Jalaladeen (2016), Kaur and Chahal (2018) and Murungi (2018) as a powerful technological tool that allows users to create content, share ideas, express opinions, disseminate information, share knowledge and exchange user-generated content.

Social media has now become an important new element of mass media and is being used to disseminate information within a very short time or in real time to a global audience (Mansell \& Hwa, 2015; Roshandel et al., 2016; Hamid et al., 2017; Kaur \& Chahal, 2018; Lopez et al., 2019). It provides user-friendly tools for knowledge sharing, enabling users to create, edit and add online contents without any professional training. It is now possible to create, edit, add and share multimedia content through videos, photos and other formats through instantaneous posts.

The focus of this study is the role played by social media in enhancing environmental awareness through CBOs in Kenya. This follows the argument by Murungi (2018) that the use of social media to share environmental issues at the community level is not common in Kenya. However, due to the multiple social networks provided by various social media tools and platforms, social media provides an ideal strategy for facilitating the sharing of knowledge and information in diverse audiences, societies and communities. Studies by Thomas and Van Dijck (2015), Rahim and Jalaladeen (2016); Roshandel et al. (2016), Murungi (2018), Severo et al. (2019) and Tsatsou (2018) posited that some of the social media sites that are popular with numerous users across the globe include Facebook, Twitter, WhatsApp, Instagram, Telegram and Flickr. Indeed, social media can play a crucial role in raising awareness on environmental issues (Roshandel et al., 2016; Du et al., 2018; Crooks et al., 2019; Lopez et al., 2019), either at the global, regional, national or even at the community level. As more people become aware of how a clean environment can influence their standard of life, the issue of conservation becomes increasingly important and can motivate them to agitate for sustainability of the environment in their communities.

Social media tools can be used to report on pollution, to create awareness, share ideas and to address queries on environmental issues. Social media networking sites can also be used as forums for activism to demand better environmental management or to seek advice for adopting sustainable environmental practices (Zhang \& Skoric, 2018).

In terms of social media activism, several studies (Thomas \& Van Dijck, 2015; Mansell \& Hwa, 2015, Murthy, 2018; Tsatsou, 2018) have looked at the role of social media in contemporary online activism and how this can be applied by CBOs in their activities. These studies demonstrated how social media activism has been used to build up and rally for community support in advocating or fighting for various causes around the world. Activists have intensified their efforts to consolidate various sources of information and 
perspectives on environmental issues in numerous social platforms. Evidently, those platforms provide an alternative forum from the main media channels, due to their ability for speedy and spontaneous reporting of environmental infringements. For them to have a wider reach, activists can employ a myriad of contemporary multimedia platforms such as blogs, micro blogging, social networking sites, instant messaging tools, video online discussion forums and email lists to communicate information. In summary, social media can be adopted by $\mathrm{CBOs}$ as a community education tool to raise awareness and campaign against environmental degradation (Hidayat \& Stoecker, 2018). In addition, governments, local authorities and other concerned entities can be engaged through the use of social media to outline their policies, campaigns and agendas in the context of environmental management.

Kenya is not an exception in the use of social media and according to the Media Council of Kenya (2016), its usage is considered high compared to some other developing countries. A recent study by Kamwaria et al. (2015) identified Facebook, Twitter and WhatsApp as the social media networking platforms mostly used in Kenya. Their high usage can be attributed to low internet costs, extensive internet connectivity coverage, upgrading of the broadband cellular network technology to $4 \mathrm{G}$ and recently to $5 \mathrm{G}$, and the affordability of web enabled electronic mobile devices.

The increase and availability of social media tools provide activists and other CBO members with an online space, which facilitates open interaction through various social networking sites (Rahim and Jalaladeen, 2016; Kaur \& Chahal, 2018). Hence, it can be used to increase environmental awareness among the local Kenyan public and provide a channel for activists in CBOs to raise their issues for the attention of national and county governments, environmental watchdogs and other concerned agencies. In addition, awareness of environmental concerns can lead to change in citizens' behaviour and practices, motivating them to report on environmental degradation activities to relevant organisations through social media networking sites and other available online tools and platforms.

\section{Objective of this study}

This study focuses on the role social media can play as a community education tool in creating environmental awareness through several CBOs in Nakuru City in Kenya. The aim of this research is to explore the use of social media in creating environmental awareness by members of these CBOs.

To achieve this objective, the following research questions were investigated:

- What is the extent of social media usage among members of the local CBOs?

- What is local CBO members' level of awareness on environmental concerns resulting from the use of social media?

- How do local CBO members use social media to highlight environmental concerns? 


\section{Methodology}

A non-probability (purposive sampling) method was used in this study. Primary data were collected from members of CBOs in Nakuru. Firstly, nine CBOs focused on environmental management, were purposively selected resulting in an accessible sample of 370 respondents. A study sample of 126 individual members was then selected. In each CBO, 14 members were purposively selected based on their consistent use of social media. The sample targeted individuals between the ages of $18-50$ years who were deemed to be active users of social media. These individuals formed the unit of analysis for this study.

To analyse the research questions, the Google Forms platform was used to create an online self-administered questionnaire, which was accessible through a link in an email sent to the respondents. The questionnaire was divided into four parts and consisted of closed-ended structured statements. The items in the first part contained general sociodemographic questions such as age, gender, education qualification, and the most preferred social media tools, among others. For the other three parts, the respondents were asked to express their opinions on a five-point Likert scale. The second part was designed to evaluate the respondents' level of social media usage. In the third part, respondents were asked to assess their level of awareness on environmental concerns. The last part considered respondents' practices in highlighting environmental concerns through social media.

The questionnaire was pre-tested in a pilot study involving 30 participants from a different setting but with similar characteristics to the study population. The questionnaire was then amended before being administered in the main study. Participants were required to voluntarily give their informed consent before taking part in the survey. Of 126 emails sent out, 98 questionnaires were completed and returned, giving the study a response rate of $77.8 \%$. Data were analysed using SPSS version 25.0 to develop descriptive and inferential statistics, which are presented in a graph and tables below.

\section{Results}

Results from the survey are presented below and describe the use of social media as a communication tool for creating environmental awareness by members of nine CBOs in Nakuru City.

\section{Respondents' demographic profile}

The distribution of the 98 members in terms of gender indicates that slightly more females $(53 \%, n=52)$ than males $(47 \%, n=46)$ were involved in the study. The majority of the respondents were aged between $21-29$ years $(29 \%, n=28), 30-39$ years $(30 \%, n=29), 40-49$ years $(25 \%, n=24)$. Those who were aged 20 years and below were $6.1 \%(n=6), 50-59$ years were $9.2 \%(n=9)$ and aged 60 and above were $2 \%(n=2)$. In terms of the level of education, $40.8 \%(n=41)$ had been educated up to secondary school level, while $38 \%$ ( $n=39)$ had at least mid-level college education. A number of the respondents $(14 \%, \mathrm{n}=14$ ) had a university education (Bachelor's degree), $5 \%(n=5)$ were post-graduates and only $2 \%(n=2)$ had only 
primary level education. Of the respondents, 68\% (n=67) affirmed that they had been using social media for five years or more, $29 \%(n=28)$ had used social media for 2-4 years and only $3 \%(n=3)$ had used social media for less than one year.

Table 1 shows the respondents' demographic information.

Table 1: Demographic profile of respondents ( $N=98)$

\begin{tabular}{|c|c|c|c|}
\hline Category & Parameter & Number of respondents & Percentage (\%) \\
\hline \multirow{2}{*}{ Gender } & Male & 46 & 47 \\
\hline & Female & 52 & 53 \\
\hline \multirow{6}{*}{ Age } & 20 and below & 6 & 6 \\
\hline & $21-29$ & 28 & 29 \\
\hline & $30-39$ & 29 & 30 \\
\hline & $40-49$ & 25 & 25 \\
\hline & $50-59$ & 9 & 9 \\
\hline & 60 and above & 2 & 2 \\
\hline \multirow{5}{*}{ Level of education } & Primary & 2 & 2 \\
\hline & Secondary & 40 & 41 \\
\hline & Middle level college & 37 & 38 \\
\hline & University undergraduate & 14 & 14 \\
\hline & University postgraduate & 5 & 5 \\
\hline \multirow{3}{*}{ Years of social media use } & 1 year and below & 3 & 3 \\
\hline & $2-4$ & 28 & 29 \\
\hline & 5 and above & 67 & 68 \\
\hline
\end{tabular}

\section{Popularity of various social media platforms}

Various social media platforms were popular among CBO members. Facebook followed by WhatsApp were the most popular social media platforms used by members of the CBOs. These were followed by Twitter and the least used was Instagram. Figure 1 shows the usage of social media platforms. 
Figure 1: Popularity of social media platforms ( $N=98)$

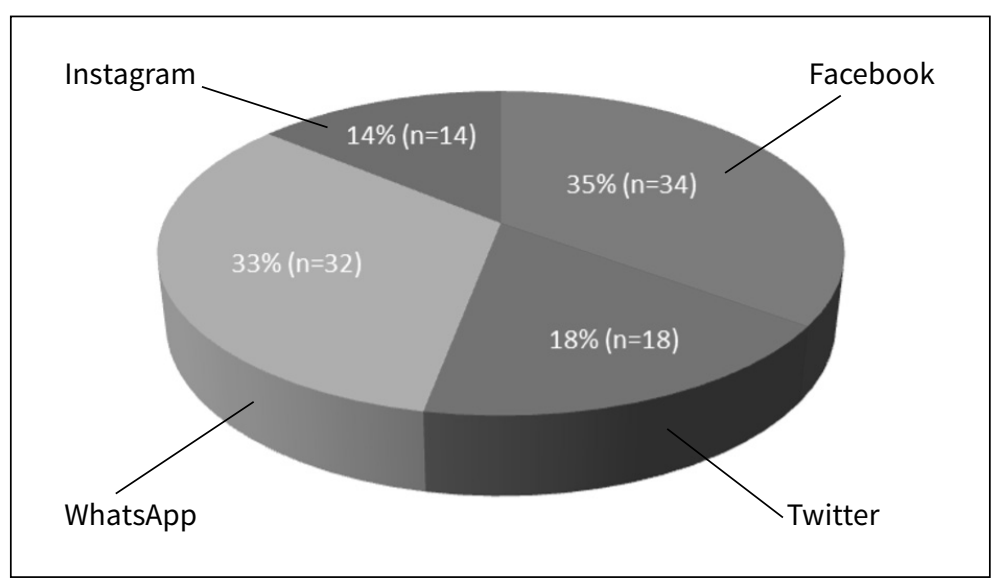

\section{Respondents' perceptions on the use of social media}

Overall, 35\% ( $n=34)$ of the respondents agreed with the research statements on social media usage. A further $27 \%(n=27)$ strongly agreed (see Table 2$)$. In particular, the majority indicated that social media formed part of their daily routine/activity and in addition, most (72\%, $\mathrm{n}=71$ ) enjoyed using social media. Most respondents were signed up to various social media networking sites, with Facebook being the most popular as shown in Table 2. It can be inferred from the findings that due to its popularity, social media forms an ideal social learning environment for environmental awareness.

Table 2: Social media usage $(N=98)$

\begin{tabular}{|l|l|c|c|c|c|c|c|c|}
\hline No. & Factor & Mean & S.D & $\begin{array}{l}\text { Strongly } \\
\text { disagree }\end{array}$ & Disagree & Neutral & Agree & $\begin{array}{l}\text { Strongly } \\
\text { agree }\end{array}$ \\
\hline 6.a & $\begin{array}{l}\text { Social media is part of } \\
\text { my everyday activity }\end{array}$ & 3.57 & 1.377 & 13 & 12 & 8 & 37 & 30 \\
\hline 6.b & $\begin{array}{l}\text { I enjoy using various } \\
\text { social media platforms }\end{array}$ & 3.68 & 1.198 & 8 & 11 & 9 & 47 & 25 \\
\hline $6 . c$ & $\begin{array}{l}\text { I feel out of touch when } \\
\text { I haven't logged on to } \\
\text { social media platforms } \\
\text { for a while }\end{array}$ & 3.34 & 1.347 & 14 & 14 & 16 & 35 & 21 \\
\hline $6 . d$ & $\begin{array}{l}\text { I would be upset if social } \\
\text { media platforms shut } \\
\text { down }\end{array}$ & 3.28 & 1.398 & 16 & 15 & 15 & 31 & 23 \\
\hline 6. fown & $\begin{array}{l}\text { I am a member } \\
\text { of multiple social } \\
\text { networking sites }\end{array}$ & 3.53 & 1.356 & 9 & 18 & 15 & 25 & 33 \\
\hline $6 . f$ & $\begin{array}{l}\text { I feel I am part of the } \\
\text { online community }\end{array}$ & 3.6 & 1.298 & 10 & 12 & 13 & 36 & 29 \\
\hline
\end{tabular}




\begin{tabular}{|l|l|c|c|c|c|c|c|c|}
\hline No. & Factor & Mean & S.D & $\begin{array}{l}\text { Strongly } \\
\text { disagree }\end{array}$ & Disagree & Neutral & Agree & $\begin{array}{l}\text { Strongly } \\
\text { agree }\end{array}$ \\
\hline 6.g & $\begin{array}{l}\text { Social media has had } \\
\text { a positive impact on } \\
\text { society }\end{array}$ & 3.66 & 1.192 & 8 & 7 & 22 & 36 & 28 \\
\hline & Average & $\mathbf{3 . 5 2}$ & $\mathbf{1 . 3 1}$ & $\mathbf{1 1}$ & $\mathbf{1 3}$ & $\mathbf{1 4}$ & $\mathbf{3 5}$ & $\mathbf{2 7}$ \\
\hline
\end{tabular}

\section{Respondents' awareness on environmental concerns}

Most respondents $(42 \%, \mathrm{n}=41$ ) agreed with the statements on level of awareness on environmental concerns. In particular, respondents agreed that human activity presents a problem for the environment, and the issue of deforestation was highlighted. However, $40 \%(n=39)$ of the respondents indicated that the problem of environmental pollution was beyond their control. As shown from the findings (Table 3), a sizable number of respondents $(n=70)$ had high levels of environmental awareness which could be shared through social media.

Table 3: Respondents' level of awareness on environment concerns ( $N=98)$

\begin{tabular}{|l|l|l|l|c|c|c|c|c|}
\hline No. & Factor & Mean & S.D & $\begin{array}{l}\text { Strongly } \\
\text { disagree }\end{array}$ & Disagree & Neutral & Agree & $\begin{array}{l}\text { Strongly } \\
\text { agree }\end{array}$ \\
\hline $7 . a$ & $\begin{array}{l}\text { I do find environmental } \\
\text { conservation important }\end{array}$ & 3.93 & 0.79 & 2 & 4 & 16 & 58 & 20 \\
\hline 7.b & $\begin{array}{l}\text { Industries must treat the } \\
\text { waste products before } \\
\text { discharging them into } \\
\text { the environment }\end{array}$ & 3.92 & 0.96 & 2 & 5 & 22 & 40 & 31 \\
\hline 7.6 & $\begin{array}{l}\text { Burning of fossil fuels is } \\
\text { one of the causes of air } \\
\text { pollution }\end{array}$ & 3.84 & 1.072 & 2 & 10 & 24 & 31 & 34 \\
\hline $7 . d$ & $\begin{array}{l}\text { Saving the environment } \\
\text { is important }\end{array}$ & 4.06 & 0.972 & 3 & 5 & 10 & 46 & 36 \\
\hline $7 . e$ & $\begin{array}{l}\text { Deforestation has } \\
\text { adverse effects on the } \\
\text { environment }\end{array}$ & 4 & 0.862 & 0 & 7 & 15 & 48 & 30 \\
\hline $7 . f$ & $\begin{array}{l}\text { Pollution through human } \\
\text { activities presents } \\
\text { a problem for the } \\
\text { environment }\end{array}$ & 3.98 & 0.952 & 3 & 5 & 12 & 50 & 30 \\
\hline 7.9 & $\begin{array}{l}\text { The problem of } \\
\text { environmental pollution } \\
\text { is beyond control so we } \\
\text { can't do anything now }\end{array}$ & 2.85 & 1.556 & 30 & 19 & 11 & 19 & 21 \\
\hline & & $\mathbf{3 . 8 0}$ & $\mathbf{1 . 0 2}$ & $\mathbf{6}$ & $\mathbf{8}$ & $\mathbf{1 6}$ & $\mathbf{4 2}$ & $\mathbf{2 9}$ \\
\hline
\end{tabular}




\section{Frequency of engaging in activities of environmental concerns}

The average level of frequency of using social media platforms on matters that deal with environmental concerns revealed that the respondents were neutral at 3.63 and leaning towards seldom. A total of $34 \%(n=33)$ indicated that they seldom used social media platforms for addressing environmental concerns and $27 \%(n=26)$ indicated 'never'. To a lesser extent, the findings showed that social media is sometimes used for advice on environmental improvement, as a tool for information sharing and for commenting on various environmental issues, as shown in Table 4. Based on the findings, it can be deduced that social media was rarely used for sharing environmental issues by members of CBOs.

Table 4: Frequency of engaging in activities of environmental concerns ( $N=98)$

\begin{tabular}{|c|c|c|c|c|c|c|c|c|}
\hline No. & Factor & Mean & S.D & Never & Seldom & Sometimes & $\begin{array}{l}\text { Very } \\
\text { Often }\end{array}$ & Always \\
\hline 8.a & $\begin{array}{l}\text { Advising on how } \\
\text { to improve the } \\
\text { environment in my town }\end{array}$ & 3.7 & 1.364 & 41 & 20 & 19 & 10 & 10 \\
\hline $8 . b$ & $\begin{array}{l}\text { Reporting on } \\
\text { environmental pollution }\end{array}$ & 3.77 & 1.217 & 35 & 29 & 24 & 5 & 8 \\
\hline $8 . c$ & $\begin{array}{l}\text { Reading on how } \\
\text { environmental } \\
\text { degradation can be } \\
\text { solved }\end{array}$ & 3.68 & 1.051 & 22 & 42 & 21 & 12 & 3 \\
\hline 8.d & $\begin{array}{l}\text { Sharing information on } \\
\text { environmental issues }\end{array}$ & 3.52 & 1.186 & 21 & 37 & 23 & 11 & 8 \\
\hline 8.e & $\begin{array}{l}\text { Commenting on various } \\
\text { environmental issues }\end{array}$ & 3.62 & 1.256 & 27 & 38 & 18 & 6 & 11 \\
\hline $8 . f$ & $\begin{array}{l}\text { Posting issues of } \\
\text { environmental concern }\end{array}$ & 3.56 & 1.131 & 21 & 36 & 28 & 8 & 7 \\
\hline \multirow[t]{2}{*}{$8 . g$} & $\begin{array}{l}\text { Engaging in discussions } \\
\text { on environmental issues }\end{array}$ & 3.56 & 1.149 & 21 & 37 & 27 & 7 & 8 \\
\hline & Average & 3.63 & 1.19 & 27 & 34 & 23 & 8 & 8 \\
\hline
\end{tabular}

\section{Correlations between the main variables}

The findings also showed a positive correlation between level of awareness and social media use with a correlation coefficient value of $r=.282$. This implies that a positive change in increase or decrease in social media use would be correlated with a $28.2 \%$ change in level of awareness. On the other hand, there was a negative correlation between frequency of engaging in activities of environmental concerns and social media use as well as that of level of awareness and frequency of engaging in activities of environmental concerns. See Table 5 for a summary of correlation levels. This implies that social media can be used to effectively enhance environmental awareness in CBOs. 
Table 5: Correlations between variables

\begin{tabular}{|l|l|c|l|l|}
\hline \multicolumn{2}{|l|}{ Correlations } & Social Media Use & Awareness Level & $\begin{array}{l}\text { Frequency of } \\
\text { Engaging }\end{array}$ \\
\hline \multirow{3}{*}{ Social Media Use } & Pearson Correlation & 1 & & \\
\cline { 2 - 5 } & Sig. (2-tailed) & & & \\
\cline { 2 - 5 } & $\mathrm{N}$ & 98 & & \\
\hline \multirow{3}{*}{ Awareness Level } & Pearson Correlation & .110 & 1 & \\
\cline { 2 - 5 } & Sig. (2-tailed) & .282 & & \\
\cline { 2 - 5 } & $\mathrm{N}$ & 98 & 98 & \\
\hline \multirow{2}{*}{$\begin{array}{l}\text { Frequency of } \\
\text { Engaging }\end{array}$} & Pearson Correlation & $-.413^{\star \star}$ & $-.273^{\star \star}$ & \\
\cline { 2 - 5 } & Sig. (2-tailed) & .000 & .007 & \\
\cline { 2 - 5 } & $\mathrm{N}$ & 98 & 98 & \\
\hline
\end{tabular}

${ }^{* *}$ Correlation is significant at the 0.01 level (2-tailed)

\section{Discussion of findings}

The study sought to establish the use of social media in creating environmental awareness in local CBOs. In terms of the first research question, it was established from the findings that the use of social media among the sampled $\mathrm{CBO}$ members is high and many respondents used social media in their daily activities. This implies that social media played a major role in the members' communications and hence could be used as a community education tool to create and enhance environmental awareness within the CBOs and by extension to the communities that they serve. Similar arguments have been advanced in the works of several scholars (Roshandel et al., 2016; Du et al., 2018; Kaur \& Chahal, 2018; Crooks et al., 2019; Lopez et al., 2019) who have argued that organisations need to adopt modern communication tools to create, disseminate and share environmental knowledge. Furthermore, the findings also concur with a study by Kamwaria et al. (2015) that Facebook, Twitter and WhatsApp are vibrant social networking platforms that could be used for creating environmental awareness in Kenya.

The level of awareness on environmental concerns among the respondents was high. This implies that the potential to share environmental knowledge among members of those CBOs is great. This potential can have an even greater impact if the use of social media is enhanced. The findings highlighted the need for people at all levels to understand environmental concerns affecting their communities to be able to advocate adequately for environmental mitigation and sustainability as acknowledged by a number of studies (see Du et al., 2018; Kaur \& Chahal, 2018; Lopez et al., 2019). 
The study established that social media platforms are not commonly used for highlighting environmental concerns in Nakuru City. The findings also established that CBO members do not regularly use social media to share environmental information or report environmental concerns. This implies that only a small number of CBO members appreciate the potential of using social media in sharing matters pertaining to environmental management. This also infers that social media is not considered an essential community education tool for sharing environmental information and for bridging the knowledge gaps needed to address environmental concerns in Nakuru City. The findings support the argument by Murungi (2018) that although social media was popular in discussing various issues in Kenya, it was not frequently used with regard to sharing environmental issues.

Additionally, the study revealed that social media use significantly enhanced the level of awareness on environmental awareness in the CBOs since it statistically exhibited a positive relationship with the dependent variable. This infers that social media usage is an important factor that can be used to enhance environmental awareness

\section{Conclusions and implications}

This study investigated the role of social media in creating environmental awareness at the community level in Kenya, by focusing on several CBOs. Quantitative data were collected through a survey by administering a structured questionnaire to members of the CBOs to consider their perceptions and experiences on the use of social media as a community education tool in addressing environmental concerns. This paper shows that the use of social media and the level of awareness on environmental issues are high within the CBOs, thus making it easier to develop associated environmental communication and social learning measures. Moreover, this may be supported by the positive correlation between the level of awareness and social media use.

This study has theoretical and practical implications. Its unique contribution is that it gives an insight into the use of social media as a social learning environment in creating community based environmental awareness at the local level. Findings revealed that most of the $\mathrm{CBO}$ members were consumers of social media besides having high levels of awareness on environmental issues. However, this situation did not translate to high usage of social media to communicate on environmental concerns. Thus, it could be concluded that despite its popularity as an interaction channel in Kenya, social media is not commonly used for sharing environmental issues at the community level. As for the practical implications, for $\mathrm{CBO}$ s and other similar organisations intending to enhance the use of social media for environmental education and communication, there is relevance in promoting its use in initiatives related to environmental conservation and sustainability at the community level.

This study also suggests the need to collaborate with other organisations dealing with environmental issues to train and motivate the $C B O$ members on the use of social media tools in addressing environmental issues. Thus, each $\mathrm{CBO}$ should develop unique community education programmes on the use of social media as a driver for amplifying sustainable environment and put in place mitigation measures should any members lag 
behind. However, the study had its limitations. Firstly, the scope of this study was limited to local CBOs dealing with environmental issues in Nakuru City, Kenya. Secondly, only a small non-probability sample was used to represent $C B O$ s in Kenya, hence the need to include a larger sample before a final supposition is drawn.

In conclusion, the study recommends the promotion of social media as a community education tool in addressing environmental concerns in CBOs through capacity building such as mentorship, training and other interaction forums. Finally, the study recommends the enhancement of open sharing of knowledge on environmental issues through increased participation of $\mathrm{CBO}$ members in online environmental activities. For further research, a comparative study is recommended to compare the use of social media as community education tool in different categories of organisations dealing with environmental issues to validate whether the findings can be generalised to other organisations.

\section{Notes on Contributor}

Waititu, Paul

Dr Waititu is a lead researcher in the Department of Health Services, County Government of Nakuru, Kenya and holds a PhD in Communication from University of South Africa. Scholarly interests include communication, environmental and health issues.

\section{References}

Bramwell-Lalor, S., Ferguson,T., Gentles, C.H. \& Roofe, C. (2020). Project-based learning for environmental sustainability action. Southern African Journal of Environmental Education, 36, 57-71.

Calitz, A., Cullen, M. \& Odendaal, F. (2020). Creating environmental awareness using an eco-feedback application at a higher education institution. Southern African Journal of Environmental Education, 36, 1-43.

Chung, K.S.K. \& Crawford, L. (2016). The role of social networks theory and methodology for project stakeholder management. Proceedings of the 29th World Congress International Project Management Association (IPMA) 2015, Westin Playa Bonita, Panama, 28 September-1 October 2015. Retrieved from https://www.sciencedirect.com/science/ article/pii/S1877042816308874.

Du, Y., Wang, X., Brombal, D., Moriggi, A., Sharpley, A. \& Pang, S. (2018). Changes in environmental awareness and its connection to local environmental management in water conservation zones: The case of Beijing, China, Sustainability, 10(2087), 2-24.

Ferronato, N. \& Torretta, V. (2019). Waste mismanagement in developing countries: A review of Global Issues International. Journal of Environmental Research and Public Health, 16(1060), 2-28.

Granovetter, M.S. (1973). The strength of weak ties. American Journal of Sociology, 78(6), 1360-1380. 
Granovetter, M.S. (1983). The strength of weak ties. A network theory revisited. Sociological Theory, 1(1983), 201-233.

Hamid, S., Ijab, M.T., Sulaiman, H., Anwar, R.M. \& Norman, A.A. (2017). Social media for environmental sustainability awareness in higher education. International Journal of Sustainability in Higher Education, 18(4), 474-491.

Hidayat, D. \& Stoecker R. (2018). Community-based organizations and environmentalism: How much impact can small, community-based organizations working on environmental issues have? Journal of Environmental Studies and Sciences, 8, 395-406.

Kamwaria, A.N., Kamau, J.M., Githaiga, A.J., Guantai, P.M., Mugwe, R., Makin, K.R. \& Dida, G.B. (2015). Socialising government: Evaluating the role of social media in governance and ethics in Kenya. International Journal of Humanities and Social Science, 5(1), 117-122.

Kane, G., Alavi, M, Labianca, J. \& Borgatti, S. (2014). Integrating social networks and information systems: A review and framework for research. MIS Quarterly, 38(1), 275-304.

Kaur, A. \& Chahal, H.S (2018). Role of social media in increasing environmental issue awareness. Journal of Arts, Science and Commerce, 9(1), 19-27.

Lopez, B.E., Magliocca, N.R. \& Crooks, A.T. (2019). Challenges and opportunities of social media data for socio-environmental systems research. Land, 8(107), 1-18.

Mannucci, P.N. \& Franchini, M. (2017). Health effects of ambient air pollution in developing countries. Journal of Environmental Research and Public Health, 14(1048), 1-8.

Mansell, R. \& Hwa, P. (2015). Social media and activism. In The International Encyclopedia of Digital Communication and Society. Oxford, UK : Wiley-Blackwell. pp. 1027-1034.

Media Council of Kenya. (2016). The impact of digital technologies and Internet on media and journalism in Kenya. Nairobi: Media Council of Kenya. Retrieved from https://issuu.com/mediacouncilkenya/docs/digital media in kenya book 2 .

Murthy, D. (2018). Introduction to social media, activism, and organizations. Social Media + Society, January 2018. doi: 10.1177/2056305117750716.

Murungi, K.M. (2018). Influence of social media to community development: Lessons from Kenya. International Journal of Social Science and Technology, 3(6), 51-122.

Nazeer, M., Tabassum, U. \& Alam, S. (2016). Environmental pollution and sustainable development in developing countries. Pakistan Development Review, 55(4), 589-604.

Omar, M.K., Dahalana, N.A. \& Yusoff, Y.H.M. (2016). Social media usage, perceived team-efficacy and knowledge sharing behaviour among employees of an oil and gas organisation in Malaysia. Procedia Economics and Finance, 37, 309-316.

Rahim, M. \& Jalaladeen, J. (2016). The role of social media on environmental awareness of undergraduate students in University of Sulaimani in Iraq. Journal of Arts, Literature, Humanities and Social Sciences, 10, 218-231. 
Roshandel, A.T., Labafi, S. \& Robati, M. (2016). Effects of social media on the environmental protection behaviour of the public (Case study: Protecting ZayandehRood river environment). International Journal of Environmental Research, 10(2), 237-244.

Saepudin, A. \& Mulyono, D. (2019). Community education in community development. Empowerment, 8(1), 64-72.

Sembiring, M. (2019). Global waste trade chaos: Rising environmentalism or costbenefit analysis? NTS Insight, No. IN19-02 (Singapore: RSIS Centre for NonTraditional Security Studies). Retrieved from https://www.rsis.edu.sg/wp-content/ uploads/2019/07/NTS-Insight-Global-waste-trade 010719.pdf.

Severo, E.A., De Guimaraes, J.C.F., Dellarmelin, M.L. \& Ribeiro, P.P. (2019). The influence of social networks on environmental awareness and the social responsibility of generations. Brazil Business Review. doi: 10.15728/bbr.2019.16.5.5.

Thomas, P. \& Van Dijck, J. (2015). Social media and activist communication.In C. Atton (ed.), The Routledge Companion to Alternative and Community Media. London: Routledge. pp. 527-537.

Tsai, T. (2012). Social networks in the information horizons of undergraduate students. Journal of Library and Information Studies, 10(1), 19-45.

Tsatsou, P. (2018). Social media and informal organisation of citizen activism: Lessons from the use of Facebook in the sunflower movement. Social Media + Society, 4(1), $1-12$.

United Nations Environment Programme. (2019). Emissions Gap Report 2019. Nairobi: UNEP. Retrieved from https://www.unep.org/resources/emissions-gap-report-2019.

Zhang, N. \& Skoric MM. (2018). Media use and environmental engagement: Examining differential gains from news media and social media. International Journal of Communication, 12, 380-403. 